\title{
REGULATORY CONFLICT: MARKET INTEGRITY vs. FINANCIAL STABILITY*
}

\author{
Chester S. Spatt**
}

\section{INTRODUCTION}

The market crisis has highlighted the design of our financial regulatory system and to a degree identified some tensions within our current system. In turn, this provides a natural opportunity to reflect upon the underlying objectives of regulation and how various regulatory goals can clash.

This Article's approach will be to use a number of prominent examples from the market crisis and tie these to central objectives of regulation. In particular, I emphasize the interaction between (a) a "Financial Stability Regulator" focused upon traditional prudential supervision and the "safety and soundness" of the financial system as a whole with (b) a regulator focused upon "fair rules of conduct," which I refer to as a "Market Integrity Regulator." Of course, this bifurcation is an abstraction, ${ }^{1}$ but a helpful one for understanding the potential conflict in regulatory goals.

In laying a background foundation for these two types of regulators, it is helpful to recognize the underlying market failures that give rise to these types of regulation. For example, an important role of a financial stability regulator

\footnotetext{
* This paper was prepared for presentation in conjunction with the University of Pittsburgh Law School's Symposium on "The Past, Present, and Future of the SEC." I thank for helpful feedback the participants at presentations at the University of Pittsburgh Law School Symposium, the Office of Economic Analysis at the Securities and Exchange Commission, the University of Oklahoma, and an informal panel presentation at the Foundation for the Advancement of Research in Financial Economics Conference and especially thank Jonathan Sokobin for suggesting the topic. The author previously served as Chief Economist of the U.S. Securities and Exchange Commission (July 2004-July 2007).

** Tepper School of Business, Carnegie Mellon University and National Bureau of Economic Research.

1. This abstraction does not match exactly the division of responsibilities among our many financial regulators. For some purposes the "market integrity regulator" has some elements in common with the SEC, while the "financial stability regulator" is perhaps closest to the Federal Reserve, but the responsibilities of these regulators do not line up exactly with this description. In the United States there also are a number of banking supervisors and two regulators focused directly upon trading platforms - the Securities and Exchange Commission and the Commodities and Futures Trading Commission. The final paragraph of this paper points to examples in which the same regulator serves as both a financial stability and market integrity regulator.
} 
is to limit the adverse consequences and externalities associated with systemic risk. Many commentators point to the transmission of adverse shocks through the financial system as a central aspect of systemic risk. From this perspective systemic risk should be viewed as such an externality or market failure. Indeed, banking regulators increasingly view their role as protecting the economy. A potentially important aspect of regulation would be to mitigate the resulting negative externalities. A key aspect underlying this perspective is that the relevant regulator would have a vested interest in the outcome, which is a very different situation than for example, traditional securities regulation or refereeing the fairness and integrity of markets, ${ }^{2}$ which raises interesting credibility issues about interpreting regulatory actions. ${ }^{3}$

Frankly, the financial stability regulator is a different notion of regulation than the regulator serving as a neutral arbiter following a consistent set of standards. Similarly, the enforcement of consistent and coherent "rules of the road" on the trading system (like the police department) could be viewed as another source of public goods and illustrative of market failure. The domain of the market integrity regulator would reflect such issues as insider trading policies including disclosure requirements and outright prohibitions, the assessment of market micro-structure frictions and its ramifications for trading, anti-manipulation policies, ${ }^{4}$ and disclosure policy and its import for public offerings, proxy voting, corporate financials and mutual funds. In turn, this suggests two very different views about what are the key public goods that would not be sufficiently provided in the absence of regulation. For those emphasizing the importance of heightened regulation, there certainly is a basic conceptual ambiguity about the types of market failures and therefore, tension about what should be addressed.

I now turn to a series of examples including stress tests, disclosures related to the Bank of America and Merrill Lynch merger, enforcement actions, short sales, and fair value accounting to highlight our themes. For the various examples, I contrast the potential attitude of a "financial stability

2. This is somewhat analogous to a sports umpire rooting for a particular team (e.g., "the home team"). In a similar spirit I have been told that a former SEC Commissioner in describing the agency's role many years ago had remarked, "We're long."

3. In a somewhat different context senior government officials stretched their role by introducing some new terminology into the economic vocabulary during the spring of 2009. Due to their interest in buoying the economy, they used the term "green shoots" to signify that economic declines were slowing - though they were not comfortable assessing the state of the economy from the traditional perspective of whether the economy was declining or growing (as they would have needed to conclude that it was declining at a rapid rate).

4. The anti-manipulation theme directly relates to financial stability as well. 
regulator" versus a "market integrity regulator." I then describe an example related to options expensing in which the registrant has a vested interest in the outcome. I conclude with a brief discussion of the broader ramifications of this approach for the design of our regulatory system.

\section{STREss Tests}

One of the most interesting innovations to emerge in the bank supervision model during the financial market crisis is the use of stress tests. By using similar "stress" scenarios among the financial institutions being examined, greater uniformity and consistency across institutions emerged in the analysis. ${ }^{5}$ Supervisors also have emphasized the distinction between solvency and stress tests, but, financial theory and optimal capitalization must be related to consideration of stress scenarios and the dynamic basis of capital structure. Of course, supervision involves more than just ensuring that the financial institution has at least $x \%$ of its capital in equity.

When the stress tests were introduced and announced the initial market reaction was quite negative. ${ }^{6}$ Such a reaction was consistent with the absence of a fully articulated plan, including how the stress tests would be implemented and the results would be disclosed, as well as fears that bank supervisors would use the stress results to require substantial dilution of existing equity claims. While the final results of the stress tests were widely applauded in the marketplace, presumably because the resulting dilution was more modest than feared in the marketplace, it is relevant to reflect upon the consequence of heightened tests by the bank supervisors. In this context the question is (a) what would be the impact of telling lenders that they are subject to new tests and (b) that the potential difficulty of the tests can increase in the future? Obviously, these effects both push in the direction of reduced lending, which was certainly not the goal of policymakers.

5. Bernanke emphasized that these "cross-firm" features represented major enhancements to the bank supervision model that the bank supervisors had practiced. Ben S. Bernanke, Chairman, Federal Reserve, Keynote Address at the Federal Reserve Bank of Atlanta Financial Markets Conference: The Supervisory Capital Assessment Program (May 11, 2009), available at http://www.federalreserve.gov/ newsevents/speech/bernanke20090511a.htm. Of course, seemingly such techniques would have been obvious ones to incorporate in supervision.

6. This was illustrated by the dramatic market reaction to Secretary of the Treasury Tim Geithner's speech, "Secretary Geithner Introduces Financial Stability Plan." Timothy Geithner, Sec'y of the Treasury, Address at the Treasury Department: Introducing the Financial Stability Plan (Feb. 10, 2009), available at http://www.treas.gov/press/releases/tg18.htm. 
There is considerable scope for conflict among regulators with respect to the disclosures envisioned under the stress tests. While the financial stability regulators (e.g., the Treasury and Federal Reserve) were not explicit about the disclosures that would result from the stress tests, officials at the highest levels ${ }^{7}$ publicly discussed the ongoing stress tests. Furthermore, the list of institutions subject to the stress tests had been announced. ${ }^{8}$ This set the stage for repeated queries about the test results to institutions identified in this manner. What appeared absent was a public commitment that the test results would be announced to the public. Even as it emerged that individual banks would not "fail" the test, but could be required to obtain additional capital; there was considerable trepidation in the marketplace because of concern about the extent of potential dilution. Of course, the traditional disclosure requirements from the market integrity regulator are for disclosure of all material information. What could be more material than information about the financial viability of the firm and the need of the firm to accept further dilution? Yet the financial stability regulators did not specify an ex ante disclosure design, even though non-disclosure would not appear viable under the securities disclosure rules under which the firms operate. This illustrates the tension between financial stability regulators (who may be inclined towards not announcing the capital needs of individual financial institutions) and a hypothetical market integrity regulator that takes seriously the importance of disclosure, as part of its investor protection mission. ${ }^{9}$

The attitudes of the financial stability regulator became relatively more sympathetic to disclosure as it recognized that adverse selection was

7. These officials included the Secretary of the Treasury, the Chairman of the Federal Reserve Board and even the President (as well as key presidential aides). See generally Hearing Before the Cong. Oversight Panel, 111th Cong. (2009) (written testimony of Timothy Geithner, Sec'y of the Treasury), available at $\mathrm{http}: / / \mathrm{www}$. treas.gov/press/releases/tg94.htm. See also Press Conference by the President, President Barack Obama, (Apr. 19, 2009), available at http://www.whitehouse.gov/the_press_office/PressConference-By-The-President-In-Trinidad-And-Tobago-4/19/2009/ ("I don't want to speculate about the ahead of the release of the stress test numbers. I think what you'll see is that, not surprisingly, different banks are in different situations.").

8. These institutions included JP Morgan Chase, Citigroup, Bank of America, Wells Fargo, Goldman Sachs, Morgan Stanley, Metropolitan Life, PNC Bank, U.S. Bancorp, Bank of New York Mellon, GMAC, SunTrust, State Street, Capital One, BB\&T, Regions Financial, American Express, Fifth Third Bancorp and KeyCorp. See Bd. of Governors of the Fed. Reserve System, The Supervisory Capital Asset Program: Design and Implementation (Apr. 24, 2009), available at http://www.federalreserve .gov/newsevents/press/bcreg/bcreg20090424a1.pdf.

9. I am unaware of any public indication of an explicit conflict between the SEC and the Federal Reserve and/or the Treasury over disclosure in the context of the stress test results or even engagement by the SEC over the appropriate disclosure regime. 
"infecting" the banking system and the bulk of large financial institutions. ${ }^{10}$ Regulators recognized that, at a minimum, it was crucial to be able to "separate" the stronger institutions from weaker ones to avoid adverse selection at the market level and weakening the system.

Still, an ex ante disclosure regime is particularly appealing because the disclosure decision becomes independent of the finding. This makes the actual stress test results stand on their own and not reflect selective disclosure. In contrast, in Spring 2009, it appeared that the regulators essentially had calculated preliminary results before deciding about their disclosure plans. Indeed, there was considerable ambiguity about whether the results would be disclosed at all until a few weeks before the results were announced.

The potential difference between financial stability regulation and market integrity regulation is vividly illustrated during the week prior to the release of the stress test results in May 2009. The lack of an ex ante disclosure plan was particularly striking during that week. The widespread leaking of "partial results" then was dramatic, particularly in light of the substantial revisions that still were occurring. This was not a context in which "trial balloons" would likely have been anticipated. Indeed, had these "leaks" been about corporate earnings or other events, an SEC investigation of manipulation almost certainly would have been undertaken. Yet in the context of the stress test I have not seen any reports about an investigation of such leaks and manipulation. In fact, given the centrality of the stress tests to the market, it is potentially an even more important matter than an investigation about leaks of earnings announcements.

All of this illustrates the difference in perspective between a financial stability regulator (whose focus is on stability of the system) and a market integrity regulator focused upon the integrity of disclosures. The supervisors and financial stability regulators have important information and perspectives that bear on the question of manipulation - both by corporate officials and regulators. The testimony of the relevant government officials is potentially germane, even acknowledging the potential claims of sovereign immunity by these officials as they would possess considerable information about whether the leaks were from government officials as well as the appropriateness of the disclosures by corporate executives.

10. An interesting economic interpretation in favor of full disclosure is the classic "lemons" analysis of Akerlof. See generally George A. Akerlof, The Market for "Lemons": Quality Uncertainty and the Market Mechanism, 84 Q. J. Econ. 488 (1970). 
While there are differences between a market integrity regulator and a financial stability regulator, an enhanced disclosure plan need not be adverse from the perspective of managing systemic risk. Indeed, many observers felt that the lack of transparency of the counterparty risk being borne by major financial institutions has been central to the systemic risk in our economy. Arguably, the financial stability regulators, due to their inherent focus on the worst states, have not fully appreciated the potential value of promoting disclosure and transparency for limiting systemic risk. Whether full disclosure helps mitigate or encourage systemic risk is ambiguous.

\section{The Bank of America Acquisition of Merrill Lynch}

Disclosure issues associated with the acquisition of Merrill Lynch by Bank of America also illustrate the potential clash of perspectives between a financial stability regulator and a market integrity regulator. Two important disclosure related facets of the Bank of America acquisition of Merrill Lynch concern the discovery by Bank of America of additional losses in Merrill Lynch in December 2008, and the absence of advance disclosure of almost $\$ 6$ billion in bonuses paid to Merrill Lynch personnel in January 2009, prior to the closing of the merger. The absence of explicit disclosure of the bonuses to the shareholders of Bank of America led to a \$33 million preliminary settlement between Bank of America and the Securities and Exchange Commission that was ultimately rejected by Federal District Judge Jed S. Rakoff. ${ }^{11}$ While that sanction is nominal compared to the scale of the bonuses, the Bank of America case also points to the role of corporate versus individual sanctions in securities violations. Many securities law settlements do not focus upon individuals because of the difficulty in proving the culpability of individuals and the incentives of individuals to fight against an adverse settlement due to reputational costs. ${ }^{12}$ At the same time corporate sanctions are often easy for prosecutors to obtain because the corporation ultimately has strong incentives to settle due to the costs of contesting the charges. Yet the appropriateness of corporate sanctions has been controversial for matters in

11. S.E.C. v. Bank of Am. Corp., No. 09 Civ. 68292009, WL 2916822 (S.D.N.Y. Sept. 14, 2009).

12. See, e.g., Chester Spatt, Tepper School of Business, Carnegie Mellon University, Penalties and Sanctions for Securities Fraud, Remarks before the Am. Econ. Ass'n (Jan. 6, 2007) (on file with author). In January 2010 the SEC announced that it would not bring charges against individuals related to the merger with Merrill Lynch. Subsequently, New York State Attorney General Cuomo brought charges of his own against both individuals and Bank of America related to the merger with Merrill Lynch — pointing to a different aspect of conflict among financial regulators in enforcing various facets of the securities laws. 
which the shareholders were originally victims and had been harmed. A penalty on the firm would impose additional costs upon the current shareholders. Indeed, penalty guidelines from the SEC issued at the start of $2006,{ }^{13}$ highlighted the importance for the appropriateness of corporate sanctions of whether the shareholders had been victims or beneficiaries of the securities fraud. Similarly, a portion of the concern expressed by Judge Rakoff was that the Bank of America shareholders were victims.

Ken Lewis, Bank of America's former CEO, testified that he was dissuaded from invoking the Material Adverse Changes (MAC) clause to reject the contemplated merger due to the Merrill Lynch losses. For example, Secretary of the Treasury Henry Paulsen indicated to Lewis that banking supervisors would question his suitability to lead Bank of America if Bank of America backed out of the merger and then needed more federal support, while federal authorities agreed to provide "ring-fencing" of difficult to value Merrill Lynch assets if Bank of America went ahead with the merger. The skeptical attitudes of senior Federal Reserve officials about the possibility of Bank of America rejecting the merger are reflected in an email from Richmond Federal Reserve President Jeff Lacker summarizing a conversation that he had with Federal Reserve Chairman Ben Bernanke, ${ }^{14}$ which was the focal point of an extraordinary hearing by the House Committee on Oversight and Government Reform on June 25, 2009 and testimony by the Federal Reserve Chairman about various communications.

Interestingly, the SEC initially had not brought an action against Bank of America with respect to its failure to disclose its losses on the Merrill Lynch assets prior to the Bank of America shareholder vote, though failure to publicly disclose these losses was arguably much more significant (and the losses more unexpected) than Bank of America's failure to disclose the Merrill Lynch bonuses. The SEC filed a separate suit on this issue when Judge Rakoff ruled against allowing the SEC charges on the disclosure of Merrill Lynch's losses to be combined with the on-going litigation about the Merrill Lynch bonuses. ${ }^{15}$ Of course, the testimony of senior federal officials would have been especially important with respect to a case focusing upon the disclosure of losses. Such testimony would be relevant even though the

13. Press Release, Sec. \& Exch. Comm'n, Statement of the Sec. \& Exch. Comm'n Concerning Financial Penalties (Jan. 4, 2006), available at http://www.sec.gov/news/press/2006-4.htm.

14. Email from Jeffrey Lacker, President, Federal Reserve Bank of Richmond, to staff (Dec. 20, 2008, 11:12 EST) (on file with author).

15. Bank of America and the SEC then negotiated a combined $\$ 150$ million settlement covering the two cases, which Judge Rakoff reluctantly approved on February 22, 2010. 
actions of the federal officials could be subject to sovereign immunity (as in the discussion of stress tests). Presumably, sovereign immunity does not exempt government officials from testifying in disclosure cases related to the adequacy of corporate disclosure by firms and their senior executives.

It is striking in this context that the financial stability regulators perceived that they had a huge vested interest in the completion of the merger. Of course, a market integrity regulator is not viewed as possessing a strong vested interest in the outcome. Instead, it is the enforcer of the federal securities laws, including its disclosure requirements. This example strongly illustrates the potential for considerable tension between managing systemic risk and the adequacy of corporate disclosures. Senior officials of the Treasury and the Federal Reserve strongly pushed in December 2008 for the completion of Bank of America's merger with Merrill Lynch, while the SEC later brought charges about the adequacy of the prospectus disclosures.

The attitude of the Federal Reserve towards disclosure (as well as towards the SEC) also is strongly illustrated by the New York Fed's advice to American International Group not to disclose important aspects of their agreements to make substantial payments to banks in its SEC filings in late $2008 .{ }^{16}$ In March 2009, the Vice Chairman of the Federal Reserve expressed fear that disclosure of AIG counterparties would even then undermine financial stability. Yet one of the lessons from the mortgage losses going back to 2007 is the importance of transparency of losses in containing systemic risk (also see discussion at end of Section 2).

\section{Enforcement Actions}

The various Bank of America disclosure examples use a tangible and widely discussed situation in which the financial stability regulator perceived that it had effective ownership and strong preferences about how disclosure should be handled. It also makes sense to consider a related question in the context of a financial stability regulator to reflect upon situations in which the government effectively owns a significant portion of the firm. Suppose hypothetically that the government owns much of a firm against which the market integrity regulator would like to bring an enforcement action. This raises the question of what it means to bring such an action. For example, given the substantial government ownership in such firms as Fannie Mae,

16. Sereena Ng \& Michael R. Crittenden, N.Y. Fed Told AIG to Shied Payouts, WaLL ST. J. (Jan. 8, 2010). 
Freddie Mac and Citigroup, this raises the question of the efficacy of enforcement actions in such cases. Somewhat in parallel, there has been serious substantive debate about the appropriateness of corporate sanctions, but much of the focus in this debate has shifted to the appropriateness of the market integrity regulator being too "weak."

\section{Short Sales}

An important aspect of market design that has proved highly controversial during the last few years has been the debate about short-sale regulation. While this paper is not a suitable forum to emphasize all aspects of that debate, short-sale regulation does provide a helpful example that illustrates the potential for disagreement and conflict between financial stability and market integrity regulators. A highly complicated and often criticized decision by the Securities and Exchange Commission was its decision to ban short sales on approximately 900 financially-oriented firms, while the "TARP" legislation was pending in Congress during September and October 2008. ${ }^{17}$ When the Washington Post conducted its final wrap-up interview with then SEC Chairman Chris Cox, he characterized as "the biggest mistake" that he had made at the SEC was listening to the advice of the President's Working Group and imposing the short-sale ban. ${ }^{18}$ This illustrates the potential for dramatic differences in viewpoint between the market integrity and financial stability regulators. The former chairman's later perspective on the ban undoubtedly reflected a variety of factors including the operational problems that the ban created in the marketplace (in fact, until options market makers were exempted this almost led to closure of options trading because of the inability of market makers to hedge) and liquidity shocks that hedge funds experienced and transmitted. Many critics of short selling (and arguably the SEC itself) had blamed short sellers for the prior dramatic declines in the valuation of financial services firms rather than the risk management practices of those firms and potentially the broader costs associated with illiquidity and unpredictable government policies. ${ }^{19}$ Economics teaches that asset values

17. An interesting and in-depth discussion of the context in which short-sale regulation evolved during 2008 and 2009 is provided by Erik R. Sirri, Regulatory Politics and Short Selling, 71 U. PiтT. L. Rev. 517 (2010). See also Phillip Swagel, The Financial Crisis: An Inside View, Brookings PaPers on ECON. ACTIVITy 1 (2009) (providing a Treasury perspective on the evolution of the overall crisis).

18. Amit Paley et al., SEC Chief Defends His Restraint: Cox Rebuffs Criticism of Leadership During Crisis, WASH. Post, Dec. 24, 2008, http://www.washingtonpost.com/wp-dyn/content/article/ 2008/12/23/AR2008122302765_3.html?sid=ST2008122302866.

19. This latter theme was highlighted in my Western Finance Association Distinguished Speaker 
decline (even absent short selling) when buyers are not willing to pay as much as previously (indeed, there are many potential buyers in the economy compared to short sellers due to the high frictional costs of short selling). ${ }^{20}$

Of course, it may have been convenient for some Wall Street CEOs to blame short sellers for the decline in their firms' valuation and indeed, indications are that at least some of these CEOs had the ear of members of the President's Working Group. Given the involvement of the Wall Street firms in all aspects of the marketplace, it is striking that at least some weighed in so aggressively against the arbitrage and trading aspects of their firms' traditional business. The comment by Chairman Cox during his wrap-up interview reflects the view that not all wisdom about regulation would be based within financial stability regulators, and there are important institutional differences in perspective among regulators. ${ }^{21}$ It is important to recognize that the role of financial regulators is not to "wish" for high asset prices, but to have a fair process for equilibrating market forces. ${ }^{22}$

One of the major ongoing costs incurred by the market integrity regulator by this ban was a continuing lack of clarity about how market design might be altered in the event of future crises. An important dislocation that resulted in the immediate aftermath of the ban was the huge stresses that hedge funds faced, which resulted in considerable withdrawal of liquidity from the marketplace. It is hard to see how such developments could be viewed as positive, either in the short term or over the longer run.

address. See Chester Spatt, Tepper School of Business, Carnegie Mellon University, Distinguished Speaker Address, Economic Principles, Government Policy and the Market Crisis (June 2009).

20. See Douglas Diamond et al., Constraints on Short-Selling and Asset Price Adjustment to Private Information, 18 J. FIN. ECON. 277 (1987).

21. In congressional testimony when the $\$ 700$ billion TARP bailout bill was pending, Chairman Cox pointed to the ban on short selling as reflecting the SEC's close working relationship with the other members of the President's Working Group. See Turmoil in US Credit Markets Recent Actions Regarding Government Sponsored Entities, Investment Banks and Other Financial Institutions: Hearing Before the S. Comm. on Banking, Housing, \& Urban Affairs, 110th Cong. (2008) (statement of Christopher Cox, Chairman, Sec. \& Exch. Comm'n).

22. Ekkehart Boehmer, Charles Jones \& Xiaovan Zhang, Shackling Short Sellers: The 2008 Shorting Ban (Samuel Curtis Johnson Sch. Research Paper Series Working Paper No. 34-09, 2009) (examining the empirical impact of the ban); Robert Battalio \& Paul Schultz, Regulatory Uncertainty and Market Liquidity: The 2008 Short Sale Ban's Impact on Equity Options Markets (2008) (unpublished manuscript, on file with author). 


\section{Fair Value Accounting}

Considerable attention has been paid during the financial market crisis to the accounting disclosure system, which defines the accounting rules for information production that would be most useful. While the traditional purpose of the design of accounting rules is to establish an information production system that would be of the most use to equity investors, it is striking that the financial stability regulator and bank supervisors as well as many market participants feel that they have a vested interest in the outcome. Analogously, banking officials feel that they have a vested interest in the accounting treatment. ${ }^{23}$ While fair value accounting itself has been very controversial - indeed, an interesting conceptual argument against fair value accounting for the "toxic" assets is that the valuation changes in the market reflect changes in the pricing of risk and liquidity, an important issue deserving more attention is whether financial and regulatory accounting should be bundled together. ${ }^{24}$ Financial stability regulators have been reluctant to depart from the financial accounting system for regulatory purposes. At the core of many of the complaints against fair value accounting is in its use for regulatory accounting and especially for the determination of an institution's capital requirements. However, this is not obviously the goal of an underlying financial accounting system that would be selected by a regulator oriented towards market integrity.

\section{Market-Based Approaches to Options Expensing}

Though it does not fit the setting of a financial stability regulator, an interesting example that illustrates the market integrity regulator context and the preferences of an interested party among alternative outcomes is the nature of the regulatory standard for accounting for market-based approaches to option expensing. The goal is to select a measurement procedure that measures and estimates the expenses most accurately. Like the analogy to a financial stability regulator, this suggests that the measurement objective and

23. For example, the American Bankers Association is not supportive of fair value accounting and on "safety and soundness" grounds wants to allow a systemic risk regulator to determine accounting disclosures for financial firms. Roderick M. Hills et al., Don't Let Banks Hide Bad Assets, Wall St. J., Nov. 18, 2009, at OP. ED. (critiquing the previous example).

24. See, e.g., John Heaton et al., Is Mark-to-Market Accounting Destabilizing? Analysis and Implications for Policy, 57 J. Monetary Econ. 64 (2010). To what extent are legal restrictions an impediment to unbundling, i.e., is it problematic for the regulator to have discretion incremental to the accounting standard? 
standard should not be one that reflects the vested interest of one of the parties. Of course, in the options expensing context the registrant issuing options will favor a marketed instrument and mechanism that leads to relatively low valuations. The registrant is much more likely to issue such market-based options provided they can design the instrument and trading process to obtain low valuations (the registrant, like the financial stability regulator in much of this paper, has a vested interest in the outcome). But this is simply not the objective of the accounting standard and the criterion that reflects the market integrity regulator's objective. ${ }^{25}$ Indeed, the extent that the registrant has the ability to select among alternative approaches would influence whether the objective of the accounting standard will be satisfied.

\section{Concluding Observations}

The examples that I cite illustrate the illusive nature of reaching regulatory goals and the potential conflicts in achieving those goals. Given the conflict in goals between different regulators and how these conflicts should operate in diverse contexts, it is not clear what is the best regulatory policy in specific situations. ${ }^{26}$ But it seems problematic to be encouraging stronger regulation per se as a single regulator doesn't have a clear way to proceed and the meaning of stronger regulation is not well defined.

One might conclude from this discussion of the multiplicity of regulatory goals that this be best handled by explicitly empowering diverse regulators. The various contexts discussed here certainly suggest that a single regulator would not emphasize goals that it did not feel important, but, of course, a primary regulator could largely ignore or bully the secondary regulator in any

25. See also Stephen Ross et al., Compensation Valuation, Inc., Zions Bancorporation ESOARS: An Evaluation (2007), available at http://www.cii.org/UserFiles/file/resource\%20center/ publications/Zion_Opinion_Final.pdf; Chester Spatt, Chief Economist and Director, Office of Econ. Analysis U.S. Sec. and Exch. Comm'n Roundtable, Wharton School of the University of Pennsylvania, Increased Importance of Models: Disclosure, Fair Value and Accounting (June 1, 2007).

26. The issue of diverse preferences among regulators also manifests itself in various contexts involving regulatory competition across countries. See, e.g., Chester Spatt, Chief Economist and Director, Office of Econ. Analysis, U.S. Sec. and Exch. Comm'n, Conference of the Autorite des Marche Financiers: Challenges to the Structure and Regulation of Financial Markets (May 14, 2007). This was an important issue in the middle portion of the last decade in such contexts as the strength of regulation related to Sarbanes-Oxley and whether regulatory competition would lead to a "race to the bottom" or a "race to the top." See, e.g., Ethiopis Tafara, A Race to the Top: International Regulatory Reform Post Sarbanes-Oxley, INT'L Fin. L. REV. (2006). This tension and the potential to try to coordinate to resolve it is illustrated by attempts by the G-20 to address compensation practices and "say on pay" rules in the face of different compensation models internationally. 
case. Still, the financial stability regulator shouldn't necessarily be the "king" regulator. The benefits to enhanced disclosure and greater transparency in allowing the marketplace to manage systemic risk, while ambiguous, have been under-emphasized. For example, starting in late 2007, this proved to be a central issue with respect to the management of counterparty risk in the marketplace, which was at the heart of the crisis. Contrary to the generic reaction of financial stability regulators in many contexts, disclosure and management of systemic risk need not conflict.

While we have focused upon conflicts between the financial stability and market integrity regulators, in fact, in some settings the financial stability and market integrity regulators are the same entities. For example, the FSA (United Kingdom) serves as both a financial stability and market integrity regulator. In some United States contexts, such as for money market funds and clearinghouses, the regulator responsible for market integrity issues also is responsible for financial stability concerns. 


\section{REFERENCES}

George Akerlof, The Market for "Lemons": Quality Uncertainty and the Market Mechanism, Q. J. Econ. 84, 488-500 (August 1970).

Robert Battalio \& Paul Schultz, Regulatory Uncertainty and Market Liquidity: The 2008 Short Sale Ban's Impact on Equity Option Markets (2009) (unpublished manuscript, on file with author).

Ben S. Bernanke, Chairman, Federal Reserve, The Supervisory Capital Assessment Program, presented at the Federal Reserve Bank of Atlanta Financial Markets Conference (May 11, 2009), available at http://www.federalreserve.gov/newsevents/speech/bernanke20090511a .htm.

Ekkehart Boehmer, Charles M. Jones \& Xiaoyan Zhang, Shackling Short Sellers: The 2008 Shorting Ban (Jan. 31, 2009) (available at http://www.tinbergen.nl/ NYSEEuronext/TIWorkshop2009/Papers/Bo ehmerJonesZhang2009.pdf).

Douglas W. Diamond \& Robert E. Verrecchia, Constraints on Short-Selling and Asset Price Adjustment to Private Information, 18 J. FIn. Econ. 277-311 (June 1987).

Timothy Geithner, Sec'y of the Treasury, Address at the Treasury Department: Introducing the Financial Stability Plan (Feb. 10, 2009), available at $\mathrm{http} / / / \mathrm{www}$. treas.gov/press/releases/tg18.htm.

John Heaton et al., Is Mark-to-Market Accounting Destabilizing? Analysis and Implications for Policy, 57 J. MonetARY ECon. 64-75 (Jan. 2010) (Carnegie-Rochester Conference Special Issue).

Roderick Hills, Harvey Pitt \& David Ruder, Op-Ed, Don't Let Banks Hide Bad Assets, Wall St. J., Nov. 18, 2009.

Jeffrey Lacker, "The ChairMan." Email sent by Richmond Federal Reserve President Jeffrey Lacker to staff (2008).

Sereena Ng \& Michael Crittenden, N.Y. Fed Told AIG to Shield Payouts, Wall St. J., Jan. 8, 2010.

Amit Paley \& David Hilzenrath, SEC Chief Defends His Restraint: Cox Rebuffs Criticism of Leadership During Crisis, Wash. Post, Dec. 24, 2008.

Stephen Ross et al., Compensation Valuation, Inc., Zions BANCORPORATION ESOARS: An Evaluation, Report for Council for Institutional Investors, Mar. 30, 2007.

Securities and Exchange Commission v. Bank of America, 2010 WL 624581 (S.D.N.Y. 2010). 
Erick Sirri, Regulatory Politics and Short Selling, 71 U. Pitt. L. Rev. 517 (2010).

Chester Spatt, Carnegie Mellon University, Tepper School of Business, Distinguished Speaker Address at the Western Finance Association, "Economic Principles, Government Policy and the Market Crisis" (June 19, 2009).

Chester Spatt, Economic Principles, Government Policy and the Market Crisis, Western Finance Association, Distinguished Speaker Address, June 19, 2009.

Chester Spatt, Increased Importance of Models: Disclosure, Fair Value and Accounting, SEC Staff Speech, June 1, 2007.

Chester Spatt, "Penalties and Sanctions for Securities Fraud": Remarks Before the American Economic Association, SEC Staff Speech, Jan. 6, 2007.

Press Release, Sec. \& Exch. Comm'n, Concerning Financial Penalties (Jan. 4, 2006), available at http://www.sec.gov/news/press/2006-4.htm.

Phillip Swagel, The Financial Crisis: An Inside View, Brookings PAPERs on Economic Activity, at 1-63 (Spring 2009).

Ethiopes Tafara, A Race to the Top: International Regulatory Reform Post Sarbanes-Oxley, InT'L Fin. LAw REV. (2006), available at http://sec.gov/news/speech/2006/spch091106et.htm. 